\title{
Synthesis And Characterization Of Alginate Based Bioplastic With The Addition Of Nanocellulose From Sago Frond As Filler
}

\author{
${ }^{1.2}$ Nor Pana Yupa, ${ }^{1.2 .3^{*}}$ Sunardi, ${ }^{1}$ Utami Irawati \\ ${ }^{1}$ Program Studi Kimia, Universitas Lambung Mangkurat, Indonesia \\ ${ }^{2}$ Pusat Penelitian Material Berbasis Lahan Basah, Universitas Lambung Mangkurat, Indonesia \\ ${ }^{3}$ Kelompok Penelitian Ecobiomaterial, Universitas Lambung Mangkurat, Indonesia \\ norpanay1@gmail.com, sunardi@ulm.ac.id, uirawati@ulm.ac.id
}



doi crossref

https://doi.org/10.31764/justek.vXiY.ZZZ

This is an open access article under the CC-BY-SA license

\section{A. LATAR BELAKANG}

Saat ini, kemasan yang digunakan untuk mencegah makanan terkontaminasi langsung secara fisik, kimia maupun biologi berasal dari berbagai polimer sintetik seperti polyvinyl chloride (PVC), polyamide (PA), polyethylene (PE), polyethylene tereftalat (PET), polyvinyl acetate (PVA), dan lain-lain. (Prasad \& Kochhar 2014). Namun, penggunaan kemasan sintetis dapat menimbulkan dampak buruk bagi lingkungan dan juga bagi kesehatan. Solusi yang dapat diterapkan yaitu kemasan ramah lingkungan yang banyak dikembangkan saat ini adalah bioplastik (Mulyadi et al, 2017) yang bersifat biodegradable. Bioplastik adalah pengemas bahan organik yang memiliki kemiripan dengan plastik (Prasetyaningrum et al, 2010). Bioplastik berasal dari bahan alam seperti alginat, agar, lignin, karet, kitin, karagenan, gelatin, polisakarida, protein, pati, pektin, 
kitosan, asam lemak, dan lilin/wax (Prasetyaningrum et al, 2010); (Chen et al, 2009); (Coniwanti et al, 2015); (Jacoeb et al, 2014).

Alginat merupakan hidrokoloid polisakarida yang dapat dimakan, diperbaharui dan bersifat kaku yang potensial dalam pembuatan bioplastik (Nisperos, 1994). Namun kekuatan mekanis bioplastik yang berasal dari alginat bersifat lemah, karena gugus hidroksil yang bermuatan negatif pada alginat sehingga membuat ikatan antar molekulnya lemah (Anward et al, 2013). Kelemahan sifat mekanis pada alginat dapat diatasi dengan menambahkan bahan pengisi (filler) yang bertujuan untuk menambah kekuatan (strength) dan kekakuan (stiffness) (Amalina et al, 2018). Beberapa bahan pengisi (filler) yang marak digunakan oleh masyarakat contohnya seperti bahan organik (serat tumbuhan), geopolimer (lempung/clay), $\mathrm{CaCO}_{3}, \mathrm{CMC}$ dan nanoselulosa ((Ray and \& Bousmina 2005); (Kim et al, 2005); (Hardjono et al, 2016); (Muhaimin et al, 2014).

Nanoselulosa atau selulosa nanokristalin memiliki banyak manfaat terutama sebagai filler (Amalina et al. 2018), untuk meningkatkan sifat mekanik komposit (Muhaimin et al, 2014) pada beberapa bahan polimer (Wulandari et al, 2016). Nanoselulosa banyak digunakan sebagai pengisi (filler) sifat biodegradasi yang tinggi, luas permukaan yang lebih besar, kemampuan dispersi serta sifat mekanik yang lebih baik (Ioelovich, 2012).

Carreno et al. (2017) menyatakan bahwa selulosa adalah salah satu polimer alami dengan ketersediaan tinggi di muka bumi yang sumber utamanya berasal dari kayu (belian, bengkirai, jati dan meranti) dan non kayu misalnya jerami (jagung, gandum, dan padi), sisal, rami, abaka, daun nanas (Ananas comosus), kenaf, sabut kelapa, serat rumput/grass, dan lain-lain (Wulandari et al, 2016); (Arini et al, 2015); (Suryanto et al. 2013); (Hermiati et al. 2017). Pelepah sagu merupakan salah satu sumber selulosa yang cukup melimpah dengan kandungan selulosa sebanyak 41,43 \% (Dyg et al, 2018). Pemanfaatan sagu di Indonesia sangat potensial mengingat $60 \%$ areal sagu dunia berada di Indonesia dan tersebar di berbagai daerah (Gunawan et al, 2016). Tanaman sagu terdapat di beberapa wilayah di Indonesia, diantaranya Riau, Sulawesi Tenggara, Kalimantan Barat, serta Kalimantan Selatan yang terdiri dari beberapa wilayah yaitu, Kota Banjarmasin, Kabupaten Tanah Bumbu, Kabupaten Hulu Sungai Utara, Kabupaten Banjar, Kabupaten Hulu Sungai Selatan, Kabupaten Tabalong, dan beberapa tempat lainnya kecuali Kotabaru dan Banjarbaru. Kalimantan Selatan memiliki luas areal sagu 6.579 ha dengan total produksi 3.876 ton pada tahun 2015 (Direktorat Jenderal Perkebunan, 2016).

Dalam penelitian ini akan dilakukan sintesis bioplastik berbasis matriks alginat dengan penambahan nanoselulosa sebagai pengisi (fillers) dari pelepah sagu. Melalui penelitian ini diharapkan karakteristik fisik dari bioplastik meningkat.

\section{B. METODE PENELITIAN}

\section{Peralatan dan Bahan Penelitian}

Peralatan yang digunakan pada penelitian ini berupa alat-alat gelas pyrex (gelas ukur, gelas kimia, tabung reaksi, batang pengaduk, erlenmeyer, cawan porselin, corong gelas dan labu takar), soklet, hotplate, magnetic strirrer, sonikator, termometer, stopwach, pH meter, ayakan 60 mesh, Fourier Transform Infra Red (FTIR) spektrometer, spektrofotometer UV-Visible, oven, desikator, autoklaf, neraca analitik, sudip, dan micrometer. Sedangkan bahan yang digunakan pada penelitian ini adalah pelepah sagu Desa Pemakuan Kecamatan Sungai Tabuk Kabupaten Banjar, alginat, akuades, kertas saring, etanol, toluena, larutan $\mathrm{NaOH}, \mathrm{H}_{2} \mathrm{SO}_{4}$, gliserol, $\mathrm{H}_{2} \mathrm{O}_{2}$. 


\section{Prosedur Kerja}

\section{Proses pembuatan bioplatik}

Alginat seberat 3 gram dimasukan dalam akuades $100 \mathrm{ml}$ pada temperatur $60^{\circ} \mathrm{C}$ $80^{\circ}$ ditambahkan $0,5 \%$ gliserol per gram alginate. Selanjutnya dicampurkan dengan nanoselulosa dari pelepah sagu $(0 \%, 0,2 \%, 0,4 \%$, dan $0,6 \%)$ hingga homogen. Larutan ini ditempatkan pada cawan petri dan dimasukkan dalam oven untuk dikeringkan pada temperatur $50^{\circ} \mathrm{C}$ selama $16-17$ jam.

\section{Karakterisasi bioplatik}

\subsection{Pengukuran ketebalan bioplastik}

Sampel bioplastik diukur pada 5 titik yang berbeda dengan menggunakan jangka sorong (ketelitian 0,01 mm). Ketebalan bioplastik diperoleh dari hasil rata-rata pengukuran.

\subsection{Pengujian transparansi bioplastik}

Spektrofotometer UV-Visible (200-800 nm) digunakan untuk menganalisis sampel. Pengukuran dilakukan sebanyak tiga kali pengulangan. Transparansi dapat dhitung berdasarkan persamaan :

Keterangan :

$$
\text { Transparansi }=\frac{\mathrm{A}_{600}}{\mathrm{x}}
$$

A600 = absorbansi pada bilangan gelombang $600 \mathrm{~nm}$

$\mathrm{X}=$ ketebalan bioplatik ( $\mathrm{mm})$

\subsection{Pengukuran kadar air bioplastik}

Sampel bioplastik ditimbang menggunakan cawan porselin yang telah diketahui beratnya. Cawan yang berisikan sampel dikeringkan dalam oven pada temperatur $100^{\circ} \mathrm{C}-105^{\circ} \mathrm{C}$ selama 5 jam hingga beratnya konstan. Kehilangan berat tersebut dihitung secara gravimetri.

\subsection{Pengukuran kelarutan bioplastik}

Sampel dipotong berukuran $2 \times 3 \mathrm{~cm}$. Sampel selanjutnya ditempatkan pada gelas beker yang berisi $20 \mathrm{~mL}$ akuades dan didiamkan pada suhu ruang $\left(25^{\circ} \mathrm{C}\right)$ selama 1 hari selama 1 hari. Sampel disaring dan dikeringkan pada temperatur $60^{\circ} \mathrm{C}$ hingga mencapai berat konstan menggunakan oven. Persamaan Persen kelarutan dapat dihitung berdasarkan :

$$
\text { Kelarutan }(\%)=\frac{\text { Wo- } \mathrm{W}}{\mathrm{Wo}} \times 100 \%
$$

Keterangan :

$\mathrm{W}_{\mathrm{o}}=$ berat sampel sebelum dilarutkan $(\mathrm{g})$

$$
\mathrm{W}=\text { berat sampel sesudah dilarutkan }
$$

\subsection{Pengukuran transmisi uap air bioplatik}

Sampel bioplastik diletakkan di antara dua wadah yang sebelumnya dipotong berbentuk lingkaran dengan diameter $\pm 5 \mathrm{~cm}$. Masing-masing wadah diisi $20 \mathrm{ml}$ air (erlenmeyer 1) dan silika gel (erlenmeyer 2) yang telah diukur berat keringnya. Sampel dibiarkan selama 1 jam sehingga dapat dihitung nilai transmisi uap airnya berdasarkan persamaan:

Keterangan:

$$
\text { Transmisi uap air }=\frac{\mathrm{W}}{\mathrm{A}}
$$

$\mathrm{W}=$ Perubahan berat $(\mathrm{g})$

$\mathrm{A}=$ Luas permukaan bioplatik $\left(\mathrm{cm}^{2}\right)$ 


\section{Analisis Gugus Fungsi}

Perubahan gugus fungsi dari bioplastik dianalisis menggunakan instrumen ATR-

IR (500-4000 $\left.\mathrm{cm}^{-1}\right)$.

\section{HASIL DAN PEMBAHASAN \\ 1. Karakterisasi Bioplastik}

\subsection{Pengukuran kadar air pada bioplastik}

Aplikasi bioplastik sebagai kemasan primer untuk produk makanan diharapkan dapat tetap menjaga kualitas dan masa simpan produk. Kandungan air pada bioplastik menjadi hal yang harus diperhatikan agar bioplastik tidak memberikan sumbangan air yang memicu kerusakan pada produk (Rusli et al, 2017). Oleh karenanya. Kandungan jumlah air yang masih terdapat pada bioplastik hasil penelitian kali ini perlu untuk diketahui melalui proses pengukuran.

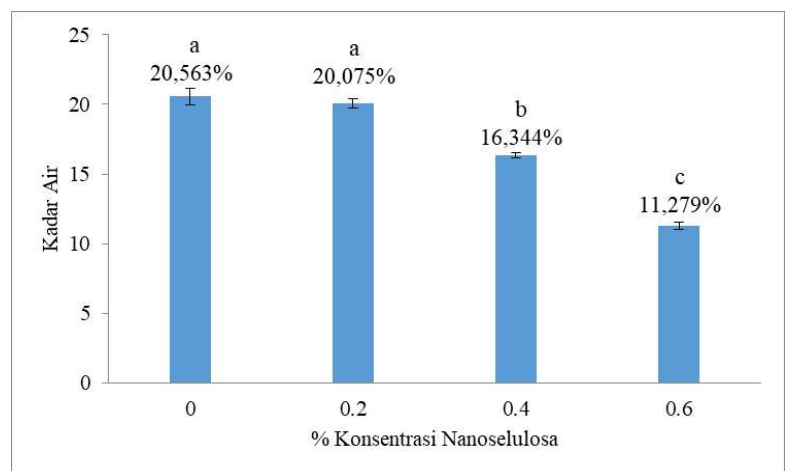

Gambar 1. Nilai Kadar Air Bioplastik

Gambar 1 menunjukkan bahwa kadar air yang dimiliki bioplastik mengalami penurunan seiring dengan peningkatan jumlah nanoselulosa $(0 \% ; 0,2 \% ; 0,4 \% 0,6 \%)$ yang ditambahkan pada matriks alginat. Penurunan nilai kadar air bioplastik dari 20,563\%, 20,075\%, 16,344\% hingga menjadi 11,279\%.

\subsection{Pengukuran ketebalan Bioplastik}

Salah satu karakteristik penting dalam penentuan kelayakan bioplastik pada penggunaanya sebagai kemasan makanan adalah ketebalan dari bioplastik. Bioplastik diharapkan memiliki ketebalan yang cukup sehingga dapat memberikan perlindungan pada produk makanan (Ariska \& Suyatno 2015). Gambar 2 menunjukan nilai ketebalan dari bioplastik pada penelitian ini.

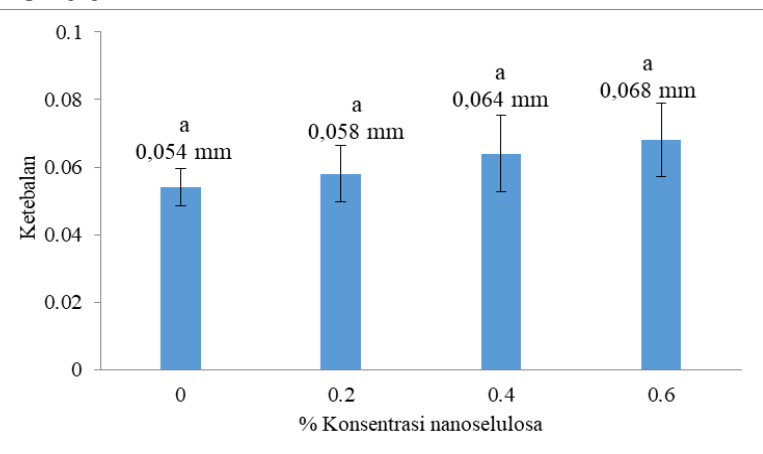

Gambar 2. Nilai Ketebalan Bioplastik

Gambar 2 menunjukkan bahwa nilai ketebalan bioplastik berbanding lurus dengan kandungan nanoselulosa yang ditambahkan pada matriks alginat. Bioplastik dengan konsentrasi nanoselulosa $0 \%$ memiliki ketebalan sebesar 0,054 mm, kemudian 
pada konsentrasi $0,2 \% ; 0,4 \%$ dan $0,6 \%$ naik menjadi $0,058 \mathrm{~mm} ; 0,064 \mathrm{~mm}$ dan 0,068 $\mathrm{mm}$. Ketebalan bioplastik pada penelitian ini memiliki karakteristik fisik bioplastik tergolong baik sesuai Japanese Industrial Standard (1975), di bawah standar maksimal yaitu $0,25 \mathrm{~mm}$.

\subsection{Pengujian transparansi}

Transparansi bioplastik secara langsung mempengaruhi penampilan dari produk yang akan dikemas. Oleh karena itu, transparansi bioplastik berpengaruh terhadap fungsional bioplastik sebagai pengemas (Qazanfarzadeh \& Kadivar 2016). Gambar 3 berikut ini menyajikan nilai dari transparansi sampel bioplastik.

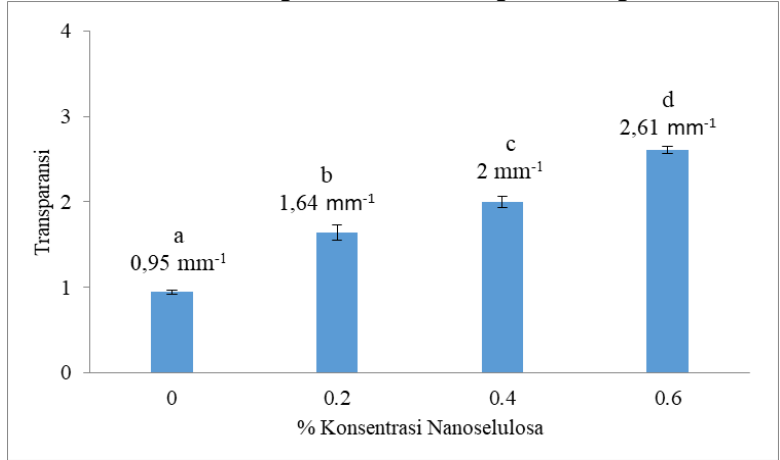

Gambar 3. Nilai Trasparansi Bioplastik

Hasil pada gambar 3 mengindikasikan bahwa penambahan nanoselulosa pada saat sintesis bioplastik meningkatkan nilai transparansi bioplastik. Nilai transparansi bioplastik dengan konsentrasi nanoselulosa 0\%; 0,2\%; 0,4\% dan 0,6\% yaitu sebesar $0,95 \mathrm{~mm}^{-1}$ kemudian naik menjadi $1,64 \mathrm{~mm}^{-1} ; 2 \mathrm{~mm}^{-1}$; dan menjadi $2,61 \mathrm{~mm}^{-1}$.

\subsection{Pengukuran transmisi uap air}

Pengukuran nilai transmisi uap air bertujuan untuk mengetahui jumlah uap airyang masuk ke dalam sistem bioplastik (Setyaningrum et al, 2017). Gambar 4 memperlihatkan hasil pengukuran nilai transmisi uap air dari bioplastik.

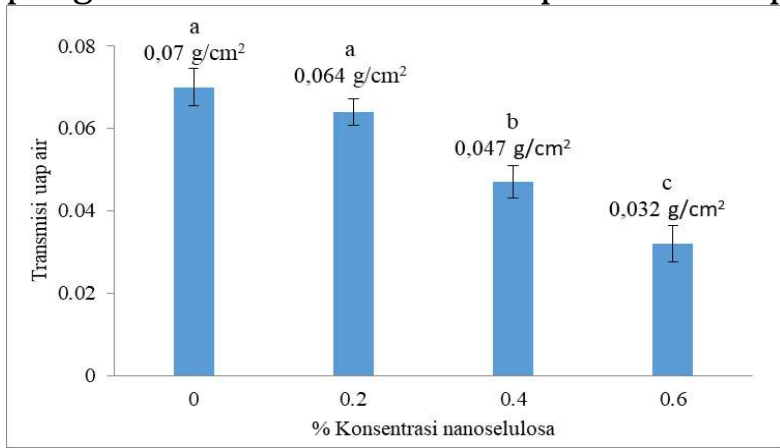

Gambar 4. Nilai Transmisi Uap Air Bioplastik

Gambar 4 menunjukkan bahwa nanoselulosa yang ditambahkan pada saat sintesis bioplastik memberikan pengaruh pada nilai transmisi uap air. Hasil pengukuran laju transmisi uap air yang dimiliki bioplastik pada penelitian ini, yaitu sebesar 0,07 $\mathrm{g} / \mathrm{cm}^{2}$ untuk bioplastik tanpa adanya penambahan nanoselulosa. Transmisi uap air kemudian mengalami penurunan nilai seiring penambahan nanoselulosa $(0,2 \% ; 0,4 \%$ dan $0,6 \%$ ) menjadi $0,064 \mathrm{~g} / \mathrm{cm}^{2} ; 0,047 \mathrm{~g} / \mathrm{cm}^{2}$ dan $0,032 \mathrm{~g} / \mathrm{cm}^{2}$.

\subsection{Pengukuran kelarutan Bioplastik}

Salah satu faktor penentu kemampuan biodegradibilitas bioplastik sebagai kemasan adalah kelarutan dari bioplastik (Diova et al., 2013). Sehingga perlu dilakukan pengukuran dari nilai kelarutan bioplastik berdasarkan kemudahan bioplastik terlarut dalam air. Gambar 5 berikut ini menyajikan nilai dari kelarutan sampel bioplastik. 


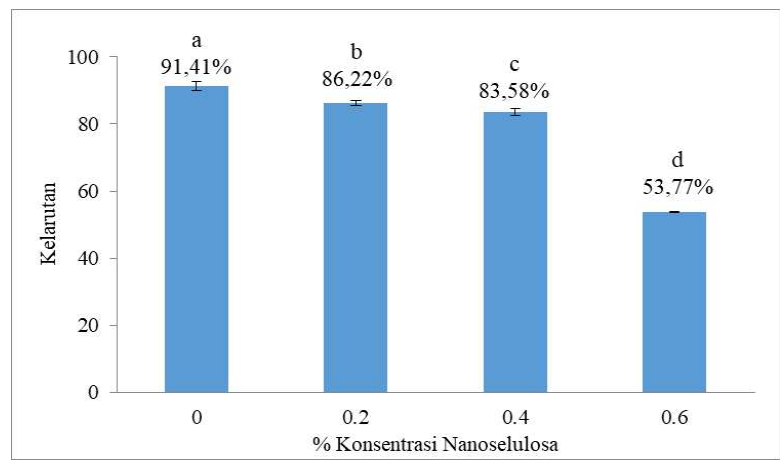

Gambar 5. Nilai Kelarutan Bioplastik

Berdasarkan gambar 5, bioplastik dengan kandungan nanoselulosa $0 \%$ memiliki nilai kelarutan dalam air sebesar 91,41\%. Nilai ini kemudian turun menjadi $86,22 \%$ pada penambahan nanoselulosa $0,2 \%$. Nilai kelarutan kembali turun menjadi $83,58 \%$ dan $53,77 \%$ pada penambahan nanoselulosa $0,4 \%$ dan $0,6 \%$. Hasil ini mengindikasikan bahwa terdapat penurunan nilai kelarutan dari bioplastik pada penelitian ini seiring dengan peningkatan kadar nanoselulosa yang ditambahkan. Fakta ini sesuai dengan pendapat Deepa et al. (2016) yang mengatakan bahwa penambahan nanoselulosa menyebabkan penurunan secara signifikan dari 8,6\% menjadi 1,7\%. Hal ini dikarenakan pembentukan ikatan hidrogen yang kuat antara gugus hidroksil nanoselulosa dan gugus hidroksil dan karboksil pada matriks bioplatik. Interaksi ini memberikan stabilitas dan ketahanan terhadap bioplastik.

\subsection{Analisis FT-IR Bioplastik}

Bioplastik yang dihasilkan dianalisis menggunakan spektrofotometer FTIR sebagai analisis gugus fungsi yang ada pada bioplastik. Gambar 6 menunjukkan puncak pada spektra FTIR dari bioplastik dengan variasi penambahan konsentrasi nanoselulosa sebesar $0 \% ; 0,2 \% ; 0,4 \%$ dan $0,6 \%$

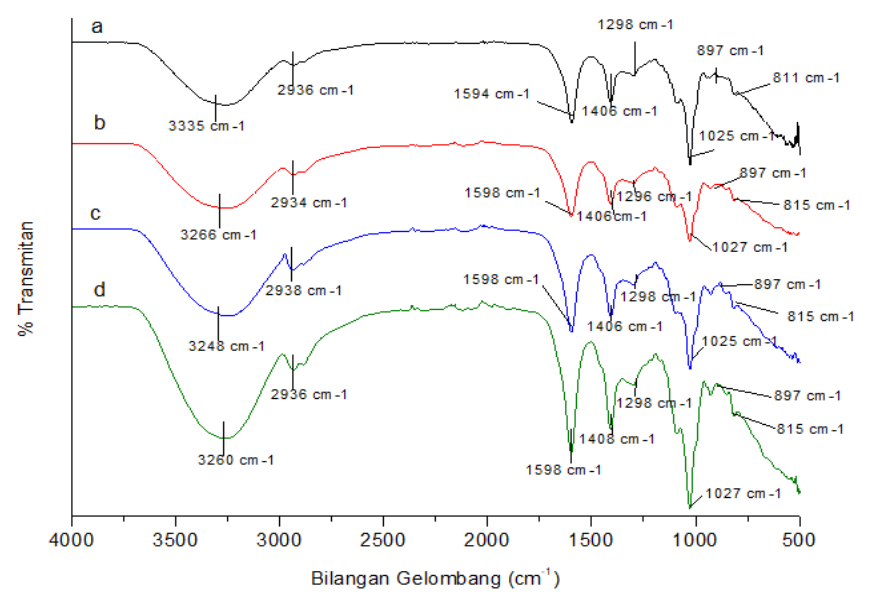

Gambar 6. FTIR bioplastik $0 \%$ (a) , bioplastik 0, 2\% (b), bioplastik 0,4\% (c) bioplastik 0,6 \%

Puncak spektra pada sekitar bilangan gelombang $3334 \mathrm{~cm}^{-1}$ mengindikasikan keberadaan regangan ikatan gugus $0-\mathrm{H}$. Intensitas puncak spektra pada daerah tersebut mengalami peningkatan seiring penambahan nanoselulosa pada matriks alginat. Seperti yang terlihat pada bioplastik 0\% puncak serapan sebesar $3335 \mathrm{~cm}^{-1}, 3266 \mathrm{~cm}^{-1}$ pada bioplastik 0,2 \%, $3248 \mathrm{~cm}^{-1}$ pada bioplastik 0,4\%, dan $3260 \mathrm{~cm}^{-1}$ pada bioplastik 0,6\%. Sedangkan pada sekitar bilangan gelombang $2930 \mathrm{~cm}^{-1}$, yang menandakan adanya gugus $\mathrm{C}-\mathrm{H}$ pada senyawa alifatik, terlihat puncak serapan yang dihasilkan yaitu $2936 \mathrm{~cm}^{-1}$ pada bioplastik 0\%, $2934 \mathrm{~cm}^{-1}$ pada bioplastik $0,2, \%, 2938 \mathrm{~cm}^{-1}$ pada bioplastik $0,4 \%$, dan 
$2936 \mathrm{~cm}^{-1}$ pada bioplastik 0,6 \% (Deepa et al., 2016). Menurut Agulhon et al., (2012), puncak serapan pada area bilangan gelombang sekitar $1405-1600 \mathrm{~cm}^{-1}$ menandakan keberadaan gugus C-O-O. Hal tersebut sesuai dengan puncak serapan $1594 \mathrm{~cm}^{-1}$ dan $1406 \mathrm{~cm}^{-1}$ pada bioplastik $0 \%, 1598 \mathrm{~cm}^{-1}$ dan $1406 \mathrm{~cm}^{-1}$ pada bioplastik $0,2 \%, 1598 \mathrm{~cm}^{-}$ 1 dan $1406 \mathrm{~cm}^{-1}$ pada bioplastik 0,4\%, $1598 \mathrm{~cm}^{-1}$ dan $1408 \mathrm{~cm}^{-1}$ pada bioplastik $0,4 \%$. Sementara itu, pada area bilangan gelombang $1290 \mathrm{~cm}^{-1}$ yang menunjukkan keberadaan gugus $\mathrm{C}-\mathrm{H}$ terlihat puncak serapan sebesar $1298 \mathrm{~cm}^{-1}$ pada bioplastik $0 \%, 1296 \mathrm{~cm}^{-1}$ pada bioplastik 0,2 \%, $1298 \mathrm{~cm}^{-1}$ pada bioplastik 0,4 \% dan 0,6 \%. Puncak serapan lainnya pada area bilangan gelombang sekitar $815-1070 \mathrm{~cm}^{-1}$ menandakan keberadaan regangan C-O (Zhang et al. 2015). Hal ini terlihat pada puncak serapan $1025 \mathrm{~cm}^{-1}$ dan $811 \mathrm{~cm}^{-1}$ pada bioplastik $0 \%, 1027 \mathrm{~cm}^{-1}$ dan $815 \mathrm{~cm}^{-1}$ pada bioplastik $0,2 \%, 1025 \mathrm{~cm}^{-1}$ dan $815 \mathrm{~cm}^{-1}$ pada bioplastik 0,4\%, $1027 \mathrm{~cm}^{-1}$ dan $815 \mathrm{~cm}^{-1}$ pada bioplastic 0,6 \% .

\section{SIMPULAN DAN SARAN}

Kesimpulan yang dapat diambil pada penelitian ini yaitu bahwa penambahan nanoselulosa dari pelepah sagu ke dalam bioplastik berpengaruh terhadap beberapa karakteristik dari bioplastik. Penambahan nanoselulosa menurunkan kadar air, laju transimisi uap air, dan kelarutan dari bioplastik. Di sisi lain, penambahan nanoselulosa memberikan peningkatan ketebalan dan trasnparansi dari bioplastik tersebut.

\section{REFERENSI}

Abdollahi, Mehdi, Mehdi Alboofetileh, Rabi Behrooz, Masoud Rezaei, and Reza Miraki. 2013. "Reducing Water Sensitivity of Alginate Bio-Nanocomposite Film Using Cellulose Nanoparticles." International Journal of Biological Macromolecules 54:166-73.

Adel, Abeer M., Zeinab H. Abd El-Wahab, Atef A. Ibrahim, and Mona T. Al-Shemy. 2011. "Characterization of Microcrystalline Cellulose Prepared from Lignocellulosic Materials. Part II: Physicochemical Properties." Carbohydrate Polymers 83(2):67687.

Agulhon, Pierre, Velina Markova, Mike Robitzer, Françoise Quignard, and Tzonka Mineva. 2012. "Structure of Alginate Gels: Interaction of Diuronate Units with Divalent Cations from Density Functional Calculations." Biomacromolecules 13(6):18991907.

Alemdar, Ayse and Mohini Sain. 2008. "Isolation and Characterization of Nanofibers from Agricultural Residues-Wheat Straw and Soy Hulls." Bioresource Technology 99(6):1664-71.

Amalina, Rizka, Dahlia Sutanto, and Bambang Sunendar. 2018. "Perbandingan Tensile Strength, Tear Strength, Dan Reproduction Of Detail Bahan Cetak Alginat Sintesis Dengan Variasi Jumlah Nanoselulosa Dan Metakaolin Terhadap Jeltrate®." SONDE (Sound of Dentistry) 3(1):1-15.

Amaliya, Riza Rizki and Widya Dwi Rukmi Putri. 2013. "Karakterisasi Edible Film Daripati Jagung Dengan Penambahan Filtrat Kunyit Putih Sebagai Antibakteri [in Press Juli 2014]." Jurnal Pangan Dan Agroindustri 2(3):43-53.

Anward, Giovanni, Yusuf Hidayat, and Nur Rokhati. 2013. "Pengaruh Konsentrasi Serta Penambahan Gliserol Terhadap Karakteristik Film Alginat Dan Kitosan." Jurnal Teknologi Kimia Dan Industri 2(2):51-56.

Arini, Neng Ayu, Mariana Bara'allo Malino, and Dwiria Wahyuni. 2015. "Analisis Pengaruh Waktu Hidrolisis Terhadap Sifat Mekanis Selulosa Kristalin Dari Campuran Serbuk Gergaji Kayu Belian, Bengkirai, Jati Dan Meranti." Positron 5(2). 
Ariska, Rizani E. and Dan Suyatno. 2015. "Pengaruh Konsentrasi Karagenan Terhadap Sifat Fisik Dan Mekanik Edible Film Dari Pati Bonggol Pisang Dan Karagenan Dengan Plasticizer Gliserol [Effect of Carrageenan Concentration on the Physical and Mechanical Properties of Edible Films from Banana Weevil Starch and Carrageenan with Glycerol as Plasticizer]." Pp. 1-5 in Prosiding Seminar Nasional Kimia. Vol. 1.

Azeredo, Henriette M. C., Luiz Henrique C. Mattoso, Delilah Wood, Tina G. Williams, Roberto J. Avena-Bustillos, and Tara H. McHugh. 2009. "Nanocomposite Edible Films from Mango Puree Reinforced with Cellulose Nanofibers." Journal of Food Science 74(5):N31-35.

Chaichi, Maryam, Maryam Hashemi, Fojan Badii, and Abdorreza Mohammadi. 2017. "Preparation and Characterization of a Novel Bionanocomposite Edible Film Based on Pectin and Crystalline Nanocellulose." Carbohydrate Polymers 157:167-75.

Chen, Yun, Changhua Liu, Peter R. Chang, Xiaodong Cao, and Debbie P. Anderson. 2009. "Bionanocomposites Based on Pea Starch and Cellulose Nanowhiskers Hydrolyzed from Pea Hull Fibre: Effect of Hydrolysis Time." Carbohydrate Polymers 76(4):60715.

Coniwanti, Pamilia, Linda Laila, and Mardiyah Rizka Alfira. 2015. "Pembuatan Film Plastik Biodegredabel Dari Pati Jagung Dengan Penambahan Kitosan Dan Pemplastis Gliserol." Jurnal Teknik Kimia 20(4).

Darni, Yuli, Herti Utami, Rina Septiana, and Rizka Aidila Fitriana. 2017. "Comparative Studies of the Edible Film Based on Low Pectin Methoxyl with Glycerol and Sorbitol Plasticizers." Jurnal Bahan Alam Terbarukan 6(2):158-67.

Deepa, B., Eldho Abraham, Laly A. Pothan, Nereida Cordeiro, Marisa Faria, and Sabu Thomas. 2016. "Biodegradable Nanocomposite Films Based on Sodium Alginate and Cellulose Nanofibrils." Materials 9(1):50.

Diova, Delia Arsi, Y. S. Darmanto, and Laras Rianingsih. 2013. "Karakteristik Edible Film Komposit Semirefined Karaginan Dari Rumput Laut Eucheuma Cottonii Dan Beeswax." Jurnal Pengolahan Dan Bioteknologi Hasil Perikanan 2(4):1-10.

Dyg, Salwani, Norhelmi Ahmad Muhammad, and Bujang Kopli. 2018. "Maximising Production of Prebiotic Sugar (Cellobiose) from Sago Frond." Malaysian Applied Biology Journal 47(1):89-95.

Fitriani, Fitriani, Syaiful Bahri, and Nurhaeni Nurhaeni. 2013. "Produksi Bioetanol Tongkol Jagung (Zea Mays) Dari Hasil Proses Delignifikasi.” Natural Science: Journal of Science and Technology 2(3).

Fuadi, Ahmad M. and Hari Sulistya. 2008. "Pemutihan Pulp Dengan Hidrogen Peroksida." Reaktor 12(2):123-28.

Gontard, Nathalie, Stephane Guilbert, and JEAN-LOUIS CUQ. 1993. "Water and Glycerol as Plasticizers Affect Mechanical and Water Vapor Barrier Properties of an Edible Wheat Gluten Film." Journal of Food Science 58(1):206-11.

Guilbert, Stéphane, Nathalie Gontard, and Leon G. M. Gorris. 1996. "Prolongation of the Shelf-Life of Perishable Food Products Using Biodegradable Films and Coatings." LWT-Food Science and Technology 29(1-2):10-17.

Gunawan, Yuspian and Prinob Aksar. 2016. "Analisa Pengaruh Ukuran Diameter Serat Tangkai Sagu Terhadap Sifat Mekanik Pada Material Komposit.” Enthalpy 1(2).

Hardjono, Hardjono, Dita Ayu Permatasari, and Vivi Alvionita Sari. 2016. "Pengaruh Penambahan Asam Sitrat Terhadap Karakteristik Film Plastik Biodegradable Dari Pati Kulit Pisang Kepok (Musa Acuminata Balbisiana Colla)." Jurnal Bahan Alam 
Terbarukan 5(1):22-28.

Haryanti, Anik and Nur Hidayat. 2017. "Analisis Penambahan Bentonit Pada Proses Pemucatan (Bleaching) Minyak Goreng Superworm (Zophobas Morio)." Journal of Food and Life Sciences 1(1).

Hermiati, Euis, Dede Heri Yuli Yanto, Ismail Budiman, Nanang Masruchin, and Bambang Subiyanto. 2017. "PROSES PEMBUATAN SERAT SELULOSA BERUKURAN NANO SISAL (Agave Sisalana) DAN BAMBU BETUNG (Dendrocalamus Asper)." JURNAL SELULOSA 44(02).

Imeson, Alan P. 2012. Thickening and Gelling Agents for Food. Springer Science \& Business Media.

Ioelovich, Michael. 2012. "Optimal Conditions for Isolation of Nanocrystalline Cellulose Particles." Nanoscience and Nanotechnology 2(2):9-13.

Jacoeb, Agoes M., Roni Nugraha, and SPSD Utari. 2014. "Pembuatan Edible Film Dari Pati Buah Lindur Dengan Penambahan Gliserol Dan Karaginan." Jurnal Pengolahan Hasil Perikanan Indonesia 17(1):14-21.

Johar, Nurain, Ishak Ahmad, and Alain Dufresne. 2012. "Extraction, Preparation and Characterization of Cellulose Fibres and Nanocrystals from Rice Husk." Industrial Crops and Products 37(1):93-99.

Kadi, Achmad. 2005. "Beberapa Catatan Kehadiran Marga Sargassum Di Perairan Indonesia." Oseana 30(4):19-29.

Kim, Hee-Soo, Han-Seung Yang, and Hyun-Joong Kim. 2005. "Biodegradability and Mechanical Properties of Agro-flour-Filled Polybutylene Succinate Biocomposites." Journal of Applied Polymer Science 97(4):1513-21.

Krochta, J. M. 1992. "Control of Mass Transfer in Food with Edible Coatings and Films." Advanced in Food Engineering 517-38.

Kwak, Hyo Won, Hohyun Lee, Subong Park, Min Eui Lee, and Hyoung-Joon Jin. 2020. "Chemical and Physical Reinforcement of Hydrophilic Gelatin Film with DiAldehyde Nanocellulose." International Journal of Biological Macromolecules 146:332-42.

Mandal, Arup and Debabrata Chakrabarty. 2011. "Isolation of Nanocellulose from Waste Sugarcane Bagasse (SCB) and Its Characterization." Carbohydrate Polymers 86(3):1291-99.

Maran, J. Prakash, V. Sivakumar, R. Sridhar, and V. Prince Immanuel. 2013. "Development of Model for Mechanical Properties of Tapioca Starch Based Edible Films." Industrial Crops and Products 42:159-68.

Moon, Robert J., Ashlie Martini, John Nairn, John Simonsen, and Jeff Youngblood. 2011. "Cellulose Nanomaterials Review: Structure, Properties and Nanocomposites." Chemical Society Reviews 40(7):3941-94.

MUHAIMIN, M. U. MINUL and Kuwat Triyana. 2014. "FABRIKASI NANOFIBER KOMPOSIT DARI NANOSELULOSA SISAL DENGAN POLYVINYL ALCOHOL MENGGUNAKAN METODE ELECTROSPINNING."

Mulyadi, Arie Febrianto, Maimunah Hindun Pulungan, and Nur Qayyum. 2017. "Pembuatan Edible Film Maizena Dan Uji Aktifitas Antibakteri (Kajian Konsentrasi Gliserol Dan Ekstrak Daun Beluntas (Pluchea Indica L.))." Industria: Jurnal Teknologi Dan Manajemen Agroindustri 5(3):149-58.

Murdinah, Murdinah, Muhamad Darmawan, and Dina Fransiska. 2007. "Karakteristik Edible Film Dari Komposit Alginat, Gluten Dan Lilin Lebah (Beeswax)." Jurnal Pascapanen Dan Bioteknologi Kelautan Dan Perikanan 2(1):19-26.

Nisperos-Carriedo, MYRNA 0. 1994. "Edible Coatings and Films Based on 
Polysaccharides." Edible Coatings and Films to Improve Food Quality 1:322-23.

Oke, Isdin. 2010. "Nanoscience in Nature: Cellulose Nanocrystals." SURG Journal 3(2):7780.

Prasad, Priyanka and Anita Kochhar. 2014. "Active Packaging in Food Industry: A Review." Journal of Environmental Science, Toxicology and Food Technology 8(5):1-7.

Prasetyaningrum, Aji, Nur Rokhati, Deti Nitis Kinasih, and Fransiska Dita Novia Wardhani. 2010. "Karakterisasi Bioactive Edible Film Dari Komposit Alginat Dan Lilin Lebah Sebagai Bahan Pengemas Makanan Biodegradable." Pp. 1411-4216 in Seminar rekayasa kimia dan proses. Vol. 2.

Qazanfarzadeh, Zeinab and Mahdi Kadivar. 2016. "Properties of Whey Protein Isolate Nanocomposite Films Reinforced with Nanocellulose Isolated from Oat Husk." International Journal of Biological Macromolecules 91:1134-40.

Rachmawati, Arinda Karina. 2009. "Ekstraksi Dan Karakterisasi Pektin Cincau Hijau (Premna Oblongifolia. Merr) Untuk Pembuatan Edible Film."

Ray, Suprakas Sinha and Mosto Bousmina. 2005. "Biodegradable Polymers and Their Layered Silicate Nanocomposites: In Greening the 21st Century Materials World." Progress in Materials Science 50(8):962-1079.

Rusli, Arham, Salengke Metusalach, and Mulyati Muhammad Tahir. 2017. "Karakterisasi Edible Film Karagenan Dengan Pemlastis Gliserol." Jurnal Pengolahan Hasil Perikanan Indonesia 20(2):219-29.

Savadekar, N. R. and S. T. Mhaske. 2012. "Synthesis of Nano Cellulose Fibers and Effect on Thermoplastics Starch Based Films." Carbohydrate Polymers 89(1):146-51.

Setyaningrum, Annisa, Ni Ketut Sumarni, and Jaya Hardi. 2017. "Sifat Fisiko-Kimia Edible Film Agar-Agar Rumput Laut (Gracilaria Sp.) Tersubtitusi Glyserol." Natural Science: Journal of Science and Technology 6(2).

Suryanto, H., Y. S. Irawan, E. Marsyahyo, and R. Soenoko. 2013. "Karakteristik Serat Mendong (Fimbristylis Globulosa): Upaya Menggali Potensi Sebagai Penguat Komposit Matriks Polimer." in National Conference. Green Technology. Vol. 3.

Tang, Qiuye, Daodong Pan, Yangying Sun, Jinxuan Cao, and Yuxing Guo. 2017. "Preparation, Characterization and Antimicrobial Activity of Sodium Alginate Nanobiocomposite Films Incorporated with E-Polylysine and Cellulose Nanocrystals." Journal of Food Processing and Preservation 41(5):e13120.

Triyastiti, Liska and Didik Krisdiyanto. 2017. "Isolasi Nanoselulosa Dari Pelepah Pohon Salak Sebagai Filler Pada Film Berbasis Polivinil Alkohol (PVA)." in Prosiding Seminar Nasional Kulit, Karet dan Plastik. Vol. 6.

Vigneshwaran, Nadanathangam, L. Ammayappan, and Qingrong Huang. 2011. "Effect of Gum Arabic on Distribution Behavior of Nanocellulose Fillers in Starch Film." Applied Nanoscience 1(3):137-42.

Wulandari, W. T., A. Rochliadi, and I. M. Arcana. 2016. "Nanocellulose Prepared by Acid Hydrolysis of Isolated Cellulose from Sugarcane Bagasse." P. 12045 in IOP conference series: materials science and engineering. Vol. 107. IOP Publishing.

Wulandari, Winda Trisna and Rosmaya Dewi. 2018. "Selulosa Dari Ampas Tebu Sebagai Adsorben Pada Minyak Bekas Penggorengan." KOVALEN: Jurnal Riset Kimia 4(3):332-39.

Zhang, Liming, Ruichao Li, Feng Dong, Aiying Tian, Zhengjun Li, and Yujie Dai. 2015. "Physical, Mechanical and Antimicrobial Properties of Starch Films Incorporated with ع-Poly-l-Lysine." Food Chemistry 166:107-14. 